\title{
PENGGUNAAN METODE PCR - RFLP (POLYMERASE CHAIN REACTION - RESTRICTION FRAGMENT LENGTH POLYMORFISM) DALAM MENDETEKSI JAMUR DERMATOFIT
}

\author{
Awaluddin $^{1)}$, Rizalinda Sjahrir ${ }^{2}$, Farida Ilyas ${ }^{2)}$ \\ ${ }^{\mathbf{1} J u r u s a n}$ Teknologi Laboratorium Medis, Universitas Megarezky, Makassar, 90234 \\ ${ }^{2}$ Fakultas Kedokteran, Universitas Hasanuddin, Makassar, Makassar, 90245 \\ Email : firstudin@gmail.com
}

\begin{abstract}
Problems: Dermatophytes is a caused by dermatophytes fungi that attack the stratum corneum, hair and nails. The aims of the research: was to identify the types of dermatophytes with PCR-RFLP methods. Research Method: This research was an observational laboratory study was performed on 23 samples collected from several clinic and primary schools in Makassar. Result: The result indicate that with PCR-RFLP all samples were positive dermatophytosis. Comprising Microsporum canis $26.1 \%$, Trichophyton rubrum $13.1 \%, T$. mentagrophytes $21.6 \%$, T. tonsurans $8.7 \%$, T. verrucosum $4.2 \%$ and unclassified species $26.1 \%$. Conclusion: Thus we suggest that this laboratory technique is used to confirm the etiology of patients with dermatophytosis.
\end{abstract}

Keywords: Dermatophyte, Dermatophytosis, PCR - RFLP

\begin{abstract}
ABSTRAK
Latar belakang: Dermatofitosis adalah penyakit akibat infeksi jamur dermatofita yang menyerang lapisan stratum korneum kulit, rambut dan kuku. Tujuan: Penelitian ini bertujuan untuk mengidentifikasi jenis jamur dermatofit dengan metode PCR-RFLP. Metode: Penelitian ini merupakan penelitian observasional laboratorium dengan dengan menguji 23 sampel yang diperoleh dari beberapa klinik dan sekolah dasar di Makassar. Hasil: Hasil penelitian menunjukkan bahwa semua sampel teridentifikasi yakni M. canis 26,1\%, Trichophyton rubrum $13,1 \%, T$. mentagrophytes $21,6 \%$, T. tonsurans $8,7 \%, T$. verrucosum $4,2 \%$ dan spesies unclassified 26,1\%. Kami menyarankan Teknik PCR-RFLP dapat digunakan untuk konfirmasi jenis jamur dermatofit.
\end{abstract}

Kata Kunci : Dermatofitosis, Jamur Dermatofit, PCR - RFLP 


\section{PENDAHULUAN}

Dermatofitosis adalah infeksi jamur yang disebabkan oleh kelompok kapang dermatofita, meliputi genus Microsporum, Trichophyton dan Epidermophyton. Kelompok kapang ini bersifat keratinofilik, menyerang lapisan superfisial tubuh, seperti : Kulit, rambut dan kuku. Microsporum dan Tricophyton biasa menyerang hewan dan manusia, sedangkan Epidermophyton hanya menyerang manusia (Sunartatie, 2010).

Prevalensi dermatofitosis zoofilik di Indonesia rendah yakni 5\% jika dibandingkan di Negara-negara barat (Setianingsih, 2015). Sedangkan di Makassar sendiri menurut penelitian yang dilakukan oleh Paramata dkk (2009), menunjukkan bahwa dermatofitosis mengenali lebih dari $20 \%$ hingga $25 \%$ populasi sehingga menjadi bentuk infeksi yang tersering.

Secara umum, dua metode yang paling penting dalam menegakkan diagnosis infeksi jamur adalah metode pemeriksaan $\mathrm{KOH} 20 \%$ dan kultur jamur, khusus metode kultur membutuhkan waktu yang cukup lama yaitu hampir sekitar 4 minggu untuk dapat mengidentifikasi jamur. Namun metode ini kurang akurat dan memakan waktu yang lama, oleh karena itu dibutuhkan metode yang lebih cepat dan akurat dalam mendeteksi jamur dermatofit ini. Garg et al (2009), mengatakan bahwa metode PCR-RFLP merupakan teknik yang digunakan untuk merestriksi untaian DNA dengan enzim restriksi sehingga memungkinkan hasil yang lebih spesifik. Metode PCR-RFLP adalah metode yang berguna untuk identifikasi dermatofit dengan cepat dan akurat.

Penelitian ini bertujuan untuk mengidentifikasi jenis jamur dermatofit pada penderita dermatofitosis di kota Makassar dengan metode PCR-RFLP.

\section{METODE PENELITIAN}

Penelitian ini dilakukan dengan metode observasional laboratorium dengan desain penelitian deskriptif kategorik. Populasi pada penelitian ini pasien dermatofitosis di beberapa klinik dan beberapa Sekolah Dasar di Kota Makassar dan sampel penelitian adalah kerokan kulit yang diperoleh dari pasien di beberapa klinik dan beberapa Sekolah Dasar di Kota Makassar. Data dikumpulkan berdasarkan penentuan tipe klinis dermatofitosis dan hasil pemeriksaan kerokan kulit KOH 10-20\% dan Tehnik PCR yang 
dilakukan di Laboratorium Mikrobologi Rumah Sakit Pendidikan Universitas Hasanuddin dan dilakukan pada bulan Maret - Juli 2016. Data yang diperoleh dikelompokkan berdasarkan tujuan dan jenis data kemudian dianalisis deskriptif. Hasil analisis akan ditampilkan dalam bentuk tabel disertai penjelasan.

Spesies unclassified dalam penelitian ini adalah spesies dermatofit yang teridentifikasi tetapi tidak menunjukkan potongan band yang sesuai dengan 6 spesies (T.mentagrophytes, T.rubrum, T.tonsurans, T.verrocosum, E.flocossum dan M.canis) menurut Mirzhahoseini et al (2009).

\section{Cara Kerja}

Metode PCR-RFLP digunakan primer ITS1 (5' TCCGTAGGTGAACCTGCGG 3') dan ITS4 (5' TCCTCCGCTTATTGATATGC 3'). Sampel dengan volume $25 \mu \mathrm{L}$ mengandung 10- $\mu 1$ 10×buffer reaksi, $100 \mu \mathrm{mol} / \mathrm{L}$ dATP, dCTP,dGTP, dan dTTP, 14,5- $\mu \mathrm{L}$ enzim kappa26, $20 \mu \mathrm{M}$ setiap primer; dan 7- $\mu$ LNA template, MgCl2 0,5- $\mu \mathrm{L}$, DMSO 1$\mu$ L. Kemudian dilakukan amplifikasi PCR. Setiap campuran reaksi dipanaskan pada suhu $94^{\circ} \mathrm{C}$ selama 5 menit. Amplifikasi PCR dilakukan dengan 39 siklus dengan kondisi berikut: $95^{\circ} \mathrm{C}$ selama 5 menit; $94^{\circ} \mathrm{C}$ selama 1 menit; $52,8{ }^{\circ} \mathrm{C}$ selama 30 detik; $72^{\circ} \mathrm{C}$ selama 1 menit dan $72^{\circ} \mathrm{C}$ selama 7 menit. Kemudian dipisahkan dengan Elektroforesis gel menggunakan $2 \%$ gel agarose kemudian dideteksi dengan menggunakan sinar UV. Kemudian, $5 \mu \mathrm{L}$ hasil ekstraksi ditambahkan $1,5 \mu \mathrm{L} \times 10$ buffer, $0,5 \mu \mathrm{L}$ (5U) dari enzim restriksi MvaI, ditambahkan nuclease free water $9 \mu \mathrm{L}$, kemudian diinkubasi pada suhu $37^{\circ} \mathrm{C}$ selama 60 menit, dilanjutkan pada proses elektroforesis gel agarosa $2 \%$ selama 90 menit dengan voltase $80 \mathrm{~V}$. 


\section{HASIL DAN PEMBAHASAN}

\section{Hasil Pengamatan}

Tabel 1. Hasil Identifikasi Jamur Dermatofit dengan Metode PCR-RFLP

\begin{tabular}{|c|c|c|c|}
\hline No. & Kode Sampel & ITS 1-4 & Enzim Mva I \\
\hline 1. & 120 & + & Microsporum canis \\
\hline 2. & 128 & + & Unclassified \\
\hline 3. & 137 & + & Microsporum canis \\
\hline 4. & 138 & + & Unclassified \\
\hline 5. & 140 & + & Microsporum canis \\
\hline 6. & 148 & + & Unclassified \\
\hline 7. & 162 & + & Microsporum canis \\
\hline 8. & 164 & + & Unclassified \\
\hline 9. & 167 & + & Trichophyton rubrum \\
\hline 10 & 168 & + & Trichophyton mentagrophytes \\
\hline 11. & 174 & + & Trichophyton rubrum \\
\hline 12. & 178 & + & Trichophyton rubrum \\
\hline 13. & 179 & + & Trichophyton mentagrophytes \\
\hline 14. & 182 & + & Microsporum canis \\
\hline 15. & 183 & + & Trichophyton tonsurans \\
\hline 16. & 185 & + & Trichophyton mentagrophytes \\
\hline 17. & 187 & + & Trichophyton verocosum \\
\hline 18. & 190 & + & Unclassified \\
\hline 19. & 195 & + & Trichophyton mentagrophytes \\
\hline 20. & 198 & + & Microsporum canis \\
\hline 21. & 199 & + & Unclassified \\
\hline 22. & 200 & + & Trichophyton mentagrophytes \\
\hline 23. & 203 & + & Trichophyton tonsurans \\
\hline
\end{tabular}

Sumber : Data Primer 2016

Berdasarkan table 1, dari total 23 sampel dermatofit dengan menggunakan metode PCR-RFLP semuanya berhasil di identifikasi. Semua DNA sampel di amplifikasi PCR dengan menggunakan primer ITS 1 - 4, kemudian di restriksi dengan enzim $M v a$ I dan di lanjutkan dengan elektroforesis gel agarose $2 \%$ untuk melihat band yang terbentuk. Adapun jenis jamur yang berhasil di identifikasi adalah $M$. canis 26,1\%, T. rubrum 13,1\%,T. mentagrophytes $21,6 \%$, T. tonsurans $8,7 \%$, T. verrucosum 4,3\% dan spesies unclassified 26,1\%. Hasil pemotongan enzim restriksi $M v a$ I mengikuti standar identifikasi dari Mirzhahoseini et al, 2009. 
1. Hasil amplifikasi PCR-RFLP

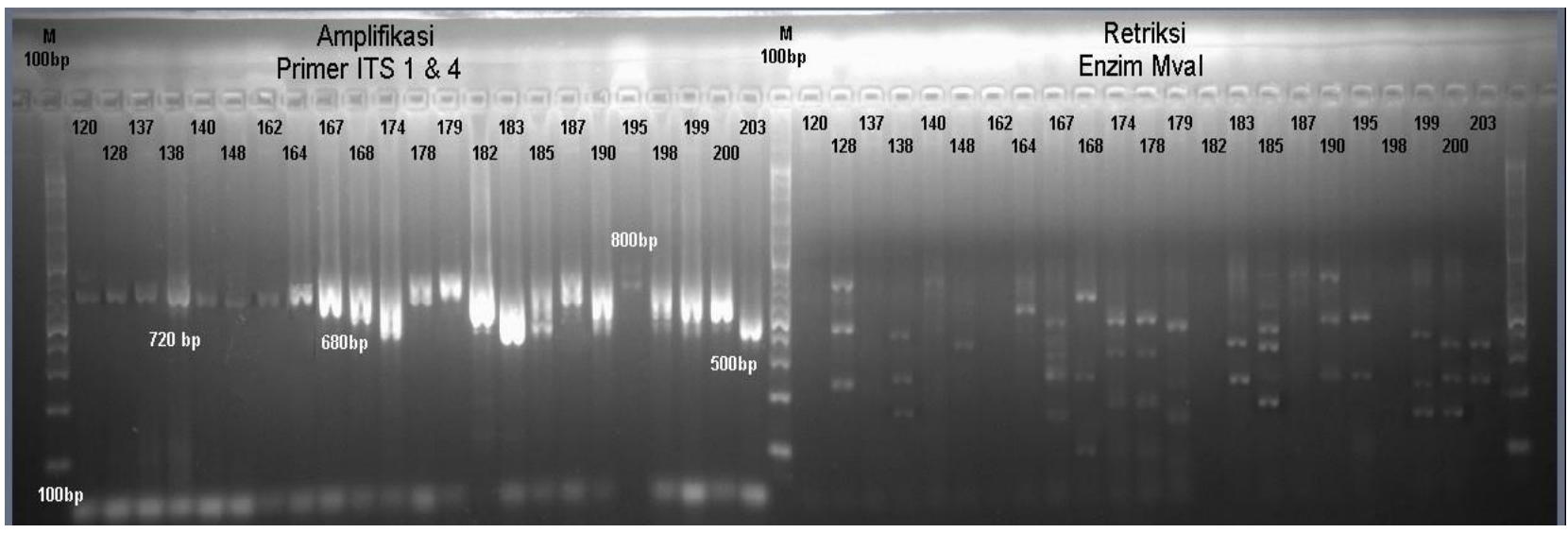

Gambar 1. A. Sebelum dipotong enzim restriksi ; B. setelah dipotong enzim restriksi

\section{Pembahasan}

Secara umum, dua metode yang paling penting dalam menegakkan diagnosis infeksi jamur adalah metode pemeriksaan $\mathrm{KOH} 20 \%$ dan kultur jamur, khusus metode kultur membutuhkan waktu yang cukup lama yaitu hampir sekitar 4 minggu untuk dapat mengidentifikasi jamur penyebab dermatofitosis (Mohammadi et al, 2015).

Berdasarkan jenis kelamin pada penelitian ini laki-laki lebih rentan terinfeksi jamur dermatofit di banding dengan perempuan, hal ini sesuai dengan penelitian yang dilakukan oleh Mirzhahoseini et al (2015), yang mengatakan laki-laki lebih sering terinfeksi di banding perempuan, hal ini dikarenakan faktor pekerjaan dimana laki-laki sebagian besar bekerja di luar ruangan dan selalu menggunakan sepatu dalam beraktifitas yang mengakibatkan kaki menjadi lembab sehingga memudahkan jamur untuk berkembang.

Metode PCR-RFLP ini mampu mendeteksi 5 spesies dermatofit yaitu Microsporum canis, Tricophyton mentagrophytes, Tricophyton rubrum, Trichophyton tonsurans dan Trichophyton verrucosum. Hasil identifikasi metode PCR-RFLP, Primer yang digunakan adalah ITS 1 dan ITS 4. Hasil amplifikasi terhadap DNA dengan menggunakan primer ITS 1 - 4 ditandai dengan terbentuknya band yang terbentuk setelah proses elektroforesis gel, kemudian dipotong dengan menggunakan enzim restriksi $M v a$ I. Pada table 1 ada beberapa sampel yang tidak dapat di identifikasi (unclasified) sampai pada tingkat spesies seperti 
pada kode sampel 128 dimana potongan bandnya berada di 250/450, kode sampel 138 dengan potongan band 160/250/450, kode sampel 148 terdapat potongan 400, kode sampel 190 dengan potongan band 250, dan kode sampel 199 pada potongan band 160/250/360, dengan demikian kode sampel tersebut dianggap sampel unclasified. Potongan band yang terbentuk pada sampel tersebut bukan merupakan potongan band target.

\section{KESIMPULAN}

Dengan PCR-RFLP teridentifikasi Microsporum canis 26,1\%, Trichophyton rubrum 13,1\%, Trichophyton mentagrophytes 21,6\%, Trichophyton tonsurans 8,7\%, Trichophyton verrucosum 4,3\% Penelitian lebih lanjut diperlukan untuk mengidentifikasi jenis jamur dermatofit dengan metode molekuler yang lain.

\section{UCAPAN TERIMA KASIH}

Terima kasih penulis ucapkan kepada Staf Laboratorium Mikrobiologi Balai Kesehatan Kulit dan Kelamin dan Laboratorium Mikrobiologi RSP Universitas Hasanuddin yang telah banyak membantu selama berlangsungnya penelitian ini.

\section{DAFTAR PUSTAKA}

Frey, D dan Oldfield,. 1979. Atlas of Pathogenic Fungi. Holland. Wolfe Medical Publications.

Khosravi, Kordbacheh, dan Bokaee. 2014. An Epidemological Approach To The Zoophilic Dermatophytoses in Iran. Medical Journal I.R. Iran. Vol.7 No. 4.

Mirzhahoseini, H,. Omidinia,E,. Ghahfarokhi, MS,. Sadeghi, G,. Abyaneh, MR., 2009. Application of PCR-RFLP to Rapid Identification of the Main Pathogenic Demartophytes from Clinical Specimens. Iranian J Publ Health, Vol. 38.

Mohammadi, R,. Abastabar, M,. Mirhendi, H,. Badali, H,. Shadzi, S,. Chadeganipour, M, Use of RFLP to Rapidly Identify Dermatophyte Species Realted to Dermatophytosis. Jundishapur J Microbiol. 2015 Juni 8 (6).

Oyeka, C. A. 2000. Trichophyton mentagrophytes a Keratinophilic fungus. In : Biology of Dermatophytes and other keratinofilik fungi. 
Paramata, N,. Maidin, A,. Massi, N., (2009). Perbandingan Uji Kepekaan Itrakonazol Terhadap Agen Penyebab Dermatofitosis Pada Kulit Glabrous di Makassar. Tesis tidak diterbitkan. Makassar : Universitas Hasanuddin.

Qomariah L., Susetiati, D., Prakosewa, R., Siswati A., Nirwati H., (2008), Uji Sensitivitas Beberapa Obat Antifungal Golongan Azole Terhadapa Dermatofita di Poliklinik RS Dr. Sardjito Yogyakarta. 20, 229-34.

Setianingsih, I., Arianti, D., Fadlily, A. 2015. Prevalence and Risk Factor Analysis of Tinea unguium infection on Pig Farmer in the Tanah Siang Sub-district, Central Kalimantan. Epidemology and Zoonosis Journal. Vol. 5, No. 3, Juni 2015.

Sunartatie, Titiek. 2010. Trichophyton mentagrophytes Sebagai Agen Penyebab Dermatofitosis Pada Kambing. Jurnal Veteriner Fakultas Kedokteran Hewan. Bogor : IPB Press. 